JAS: Jurnal Ilmiah Ahwal Syakhshiyyah

Volume 1 Nomor 2 Tahun 2019

ISSN: $2714-7398$

\title{
PANDANGAN DAN HUKUM ISLAM TERHADAP WANITA DALAM MASA IDDAH YANG BERHUBUNGAN DENGAN PRIA LAIN MELALUI MEDIA SOSIAL.
}

\author{
Ibnu Jazari \\ Fakultas Agama Islam Universitas Islam Malang \\ e-mail: ibnujazari11@gmail.com
}

Diterima: 12-10-2019 | Direvisi: 12 Desember 2019 | Disetujui: 12 Desember 2019

(C) 2019 Program Studi Ahwal Syakhshiyyah Fakultas Agama Islam Universitas Islam Malang

\begin{abstract}
Abstrak
Saat dalam era globalisasi seperti ini yang dimulai dari kecanggihan teknologi, informasi dan komukasi yang berkembang secara pesat dan semakin memberikan kemuadahan bagi siapa saja yang akan mengaksesanya, maka sosial media pun juga berkembang sangat pesat. Si pengguna media sosial pun tidak hanya para orang-orang yang bergelar doktoral saja, atau yang lainnya yang setra dengan itu, namun hampir semua orang bisa mngaksesnya mulai dari anak kecil, remaja, dewasa hingga orang tua, hal ini tidak menutup kemungkinan bahwa janda yang sedang iddah juga banyak mengaksesnya. Penelitian ini adalah menggunakan pendekatan ranah kualitatif. Penelitian ini sifatnya lebih ke arah metode kajian atas gagasan konseptual dengan data-data yang dikumpulkan dan yang akan dianalisis bertumpu pada ketersediaan sumber data di perpustakaan (Library Research). Penggunaan media sosial seperti chatting, update status, upload foto yang menyatakan dirinya dan mempertontonkan dirinya dalam masa iddah tidak dibenarkan dalam islam karena hal tersebut tidak sesuai dengan ketentuan. Hal tersebut didasarkan pada hukum tentang wnaita iddah tidak boleh keluar rumah, bersolek dan memakai make up, tidak boleh dikhitbah dan menerima khitbah dari laki-laki lain pada masa iddah.
\end{abstract}

Kata Kunci: Hukum Islam, Wanita, Iddah, Berhubungan, Pria Lain, Media Sosial

\begin{abstract}
When in the era of globalization like this, which was started from the sophistication of technology, information and education that was growing rapidly and increasingly giving the custom to anyone who would access it, then social media was also developing very rapidly. The users of social media are not only people with doctoral degrees, or others who are similar, but almost everyone can access it from children, teenagers, adults to the elderly, this does not rule out the possibility that widows are while iddah also accesses it a lot. This research uses a qualitative domain approach. This research is more towards the method of study This work is licensed under Creative Commons Attribution Non Commercial 4.0 International License Available online on: http://riset.unisma.ac.id/index.php/fai/index
\end{abstract}


of conceptual ideas with data collected and to be analyzed based on the availability of data sources in the library (Library Research). The use of social media such as chatting, status updates, uploading photos that state themselves and showing themselves in the iddah period is not justified in Islam because it is not in accordance with the provisions. This is based on the law about women iddah not to go out of the house, preening and wearing makeup, may not be preached and receive sermons from other men during the iddah period.

Keywords: Islamic Law, Women, Iddah, Relationships, Other Men, Social Media

\section{A. Pendahuluan}

Agama Islam adalah agama yang menuntun kepada umatnya untuk patuh dan menyembah kepada Allah SWT tuhan semesta alam, dalam ajaran Islam banyak tuntunan yang harus dijalani supaya manusia tidak tersjerumus ke dalam kemaksiatan yang mengakibatkan terjadinya hal buruk dalam hidup manusia.

Islam juga mengajarkan kepada Umatnya untuk selalu bertaqwa kepada Allah. Antara lain jalan menuju bertaqwa yakni dengan cara menikah. Menikah adalah suatu sarana ibadah yang harus dilakukan setiap umat manusia, Nabi Muhammad juga menuntun kepada umatnya supaya melakukan sunnahnya yakni menikah.

Menikah selain menjadi sunnah rasul tetapi juga memiliki arti yang sangat penting dalam kehidupan, memiliki nilai sosial, kemasyartkatan, individu dan lain sebaginya. Selain itu pernikahan menjadi hal yang sangat penting dalam kehidupan manusia untuk mencapai suatu kehormatan di mata masyarakat yang lain.

Adapun tujuan pernikahan yakni antara lain suapaya manusia mendapatkan keturunan untuk melangsungkan hidupnya, sebagai penyalur syahwat dan memenuhi hajatnya untuk menumpahkan kasih sayang, bentuk dari ketaqwaan kepada Allah SWT, memelihara dirinya untuk selalumenjaga dari hal kemaksiatan, menjadikan diri seseorang untuk bertanggung jawab atas dirinya, dan keinginan untuk membangun rumah tangga yang sah atas dasar agama dan atas dasar dirinya.

Setiap insan di dunia ini ingin berhasil dalam hala apapun termasuk dalam menjaga dan menjalani rumah tangga nya, namun tidak semua keberhasilan itu sesuai dengan apa yang diatakdirkan Allah kepadanya. Sebuah ikatan penikaha yang terus menerus dijaga dengan ketat demi mencapai keberhasilan tak semiuanya selalu berjalan mulus, bahkan banyak juga yang sampai kepada jalan perpisahan, baik perpisahan itu dikarenakan kematian ataupun perpisahan tersebut dikarenakan perceraian, namun dari perpisahan tersbut belum berakhir

JAS: Volume 1 Nomor 2, 2019 
semuanya, karena seusai dari perpisahan ini masih ada kewajiban yang harus dilakukan oleh sang wanita yang biasanya kita sebut dengan iddah.

Jika ada pasangan yang terjadi perceraian maka bagi para wanita ada masa tunggu, hal ini yang biasanya disebut dengan iddah, masa tunggu bagi seorang perempuan ialah semata-mata karena untuk menyelamatkan kaum perempuan dari perbuatan yang tidak di inginkan. Masa tunggu bagi perempuan ini uga terdapat dalam Alquran. Masa tunggu bagi wanita tidaklah mempunyai waktu yang sama antara masa tunggu ketika bercerai yang dikarenakan meninggalnya sang suami dengan masa tunggu karena diceraikan oleh sang suami yang dikarenakan suatu masalah yang ada dalam perjalanan dalam membangun rumah tangganya. Hal ini (masa tunggu/ iddah) ada pula perbedaan antara bagi wanita yang masih produktif dengan para wanita yang sudah tidak produktif (monopause). Dan ada perbedaan pula iddah pada wanita yang sedang mengandung.

Saat dalam era globalisasi seperti ini yang dimulai dari kecanggihan teknologi, informasi dan komukasi yang berkembang secara pesat dan semakin memberikan kemuadahan bagi siapa saja yang akan mengaksesanya, maka sosial media pun juga berkembang sangat pesat. Si pengguna media sosial pun tidak hanya para orang-orang yang bergelar doktoral saja, atau yang lainnya yang setra dengan itu, namun hampir semua orang bisa mngaksesnya mulai dari anak kecil, remaja, dewasa hingga orang tua, hal ini tidak menutup kemungkinan bahwa janda yang sedang iddah juga banyak mengaksesnya.

Saat ini dengan maraknya media sosial dan kemudahan akses internet serta jaman yang serba canggih manusia pun kebanyakan memakai alat technologi yang canggih pula, kelakuan sehari-hari pun juga memakai alat yang canggih pula. Dari kecanggihan tersebut membuat manusia semakin pintar dan semakin cepat dalam berhubungan.

Sementara itu banyak manusia yang tidak dapat memanagemant kehidupannya dalam menggunakan kecanggihan technologi yang sekarang ini antara lain dengan menggunakan media sosial sebagai penghubung dengan orang lain di waktu yang tidak tepat antara lain bagi mereka para perempuan menggunakan media sosial sebagai penghubung dengan pria lain pada saat tunggu(masa iddah).

Sebagai konsekuensi dari penggunaan media sosial yang mudah dan bebasnya mengakses akan berpengaruh positif dan negatif, seperti juga dalam keadaan iddah kalau tidak bisa memilkhnya akan berdampak negatif yakni salah satunya akan terhubung dengan pria lain dalam masa iddah dengan maksud dan tujuan tertentu yang akan memberikan jalan kepernikahan. Sehubungan dengan 
hal tersebut maka agama islam memberikan aturan dalam masalah pernikahan, talak, dan bagaimana hukumnya serta konsekuensi yang akan didapat setelah terjadinya talak bagi kaum wanita.

\section{B. Metode}

Penelitian ini adalah menggunakan pendekatan ranah kualitatif. Penelitian ini sifatnya lebih ke arah metode kajian atas gagasan konseptual dengan data-data yang dikumpulkan dan yang akan dianalisis bertumpu pada ketersediaan sumber data di perpustakaan (Library Research). Sedang untuk teknik nalisis data yang digunkan dalam kajian ini adalah teknik Analisis isi (content analysis) memahami inti dari keterangan, pesan atau informasi yang disajikan dalam wujud lambang atau simbol tertentu yang terdokumentasi atau dapat didokumentasikan.

\section{Hasil dan Pembahasan}

Hukum islam memberikan aturan terhadap suatu kelangsungan dalam pernikahan. Hukum Islam menjelaskan bahwa nikah adalah suatu perbuatan perikatan antara laki-laki dan perempuan yang didalamnya terdapat aturan yang mengatur perjalan tersebut, namaun untuk proses acara (resepsi/upacara) tidak ada aturan khusus didalamnya.

Namun pernikahan yang dilaksanakan harus sesuai dengan aturan-aturan yakni: melaksanakan ikatan persetujuan atau yang biasa disebut dengan aqad antara pria dan wanita yang berdasarkan kerelaan masing-masing kedua belah pihak dan yang dilakukan oleh wali (ayah wanita) dari pihak wanita berdasarkan ketentuan yang berlaku.

Serta perkawinan akan dinilai sah ketika perkawinan dilakukan sesuai dengan hukum islam dan suesuai dengan hukum negara yakni pasal 2 ayat (1) undang-undang no.1 tahun 1974 tentang perkaawinan. Undang-undang tersebut bertujuan untuk supaya perkawinan terjamin dalam hal ketertibannya. Dan setiap perkawinan harus dicatat oleh pegawai pencatat nikah.

Dalam pelaksanaan nya sesuai dengan ketentuan pasal 5 yakni setiap perkawinan harus dibawah pengawasan pegawai pencatat nika. Hal ini dilakukan agar masyarakat tertib akan hukum yang berlaku dan nikah tidak hanya sekedar ucapan lisan saja, meskipun dalam ucapannya menghadirkan saksi dan wali nikah sebagai bukti telah melaksanakan pernikahan, namun hal yang demikian itu belumlah cukup dan belum kuat juga payung hukumnya.

Dalam Kompilasi Hukum Islam, (1992:19) Pernikahan yang dilakukan diluar pengawasan tidak akan mempunyai payung hukum yang kuat, sehingga ketika JAS: Volume 1 Nomor 2, 2019 
Pandangan Dan Hukum Islam Terhadap Wanita Dalam Masa Iddah Yang Berhubungan Dengan Pria Lain Melalui Media Sosial.

terjadi masalah dalam perjalannanya para peagawai pengawas tidak akan bisa membantu memberikan solusi bagi pasangan tersebut.

\section{Talak}

Putusnya pernikahan selain cerai mati maka hal tersebut harus dibuktikan dengan surat keterngan cerai yang biasnya disebut dengan akta cerai dari pengadilan agama setempat. Hal ini dimaksudkan agar manusia tertib hukum dan mencegah banyaknya perceraian. Dan memudahkan ketika sang pasangan tersebut ketika ingin membina keluarga yang baru.

Putusnya pernikahan terjadi dengan berbagai alasan yakni: karena kematian, karena perceraian, karena putusan pengadilan. Putusnya pernikahan yang diakrenakan kematian yakni salah satu diantara pasangan telah meninggal dunia dan hal ini menyebabkan secara otomatis adanya perceraian (Taimiyah, 1997:115). Sedangkan putusnya pernikahan karena perceraian disebabkan oleh gugutan perceraian ataupu talak dari sang suami. Perceraian dapat disebabkan oleh banyka faktor yakni: salah satu pihak berbuat kemasiatan/ melakukan hal buruk yang tidak sesuai dengan syariat hukum islam dan hukum negara, salah satu pihak telah keluar meninggalakan salah staunya tanpa alasan selama 2 tahun berturut-turut tanpa ada kabar apapun dengan kata laing bisa disebut dengan minggat, bisa juga disebabkan salah satunya dipenjara selama 5 tahun atau hukuman yang lebih beratpadanya, melakukan kejahatan/kekejaman dalam rumah tangga(KDRT), terdapat cacat tubuh pada salah satunya yang dapat mengakibatkan tidak bisa memenuhi kewajibannya sebagai suami-istri, terdapat perselisihan yang tidak dapat diselesaikan dan tidak memungkinkan adanya kerukunan antara satu dengan yang lain, adanya pelanggaran taklik talak oleh suami, dan terjadinya pindah agama yang dilakukan oleh salah satu pihak. Dan hal tersebut (perceraian) hanya dapat dilakukan di depan pengadilan agama ketika pengadilan agama sudah tidak mampu dan tdak bisa untuk mendamiakan kedua belah pihak (Kompilasi Hukum Islam, 1992:70).

Percaraian yang biasanya disebut dengan talak yakni suatu ikrar yang diucapkan oleh suami diahadapan pengadilan agama yang mengakibatka putusnya perkawinan dan dilaksankan dengan ucapan lisan ataupun tertulis dan pihak pengadilan agama sudah tidak mampu untuk mendamaikan keduanya(Kompilasi Hukum Islam,1992:70).

Talak di bagi menjadi 6 (enam) yakni:

a. talak raj'i : yaitu suatu talak yang diajtuhkan oleh suami terhadap istri dimana kedua belah pihak masih memungkinkan untuk melakukan perdamaian 
kembali. Dalam talak raj'i ini sang suami masih berhak untuk kembali kepada istrinya tanpa melalui akad nikah yang baru dengan syarat sang istri dalam masa iddah. Atau dengan kata lain sang istri masih belum berada dalam masa yang diwajibkan untuk menunggu untuk dinikahi laki-laki yang lain. Pada hal ini sang suami boleh kembali pada sang istri tanpa harus menunggu persetujuan dari sang istri dan wali nikahnya. Hal ini dikarenakan talak raj'i masih terhitung dalam ikatan pernikahan. Dan sang istri berhak untuk mendapatkan temapat tinggal dari snag suami dalam masa iddah. Jika salah satu dari keduanya (suami/ istri) meninggal dunia, maka yang lain masih berhak untuk mendapatkan warisan dari pasangan tersebut.

b. talak ba'in (sughra dan kubra)

1) talak ba'in sughra yaitu talak yang dijatuhkan suami terhadap istrinya, namun dalam talak ini suami dan itri tidak boleh rujuk (kembali) lagi kecuali dengan akad yang baru, meskipun sang wanita dalam masa iddah. Ketika talak belum mencapai tiga kali maka talak tersebut belum bisa dikatakan talak bain sugra

Yang termasuk dalam talak ba'in sughra ini adalah: talak yang djatuhkan suami dengan syarat qobla ad dukhul, talak yang diajtuhkan karena tebusan, talak yang diajtuhkan karena putusan pengadilan agama.

2) Talak ba'in kubra yaitu talak yang dijatuhkan oleh suami terhadap istrinya yang ketiga kalinya. Dimana dalam talak ba'in kubrra ini suami dan istri tidak boleh rujuk (kembali) lagi meskipun itu sang wanita dalam masa iddah, kecuali sang wanita telah menyempurnakan iddahnya dan menikah dengan laki-laki yang lain kemudian ditalak lagi dengan syarat ba'da ad-dukhul dengan laki-laki yang kedua, kemudian sang wanita telah menyempurnakan iddahnya terhadap talak laki-laki yang kedua.

c. talak sunny yakni talak yang dibolehkan dengan kata lain talak yang dijatuhkan oleh suami terhadap istrinya yang sedang dalam keadaan suci dan tidak dicampuri pada saat suci tersebut.

d. talak bid'i yakni talak yang dilarang, yaitu talak yang dijatuhkan suami terhadap istrinya dalam keadaan haidl, atau talak yang diajtuhkan suami terhadap istrinya yang sedang suci, namun pada saat suci tersebut sang suami telah mencampurinya.

e. Khuluk yaitu talak yang dijatuhkan suami terhadap istrinya dimana sang istri telah menebus atau membayar kepada sang suami agar sang suami menjatuhkan talak terhadap dirinya. Adapun akibat dari perceraian khuluk ini ialah dapat mengurangi jumlah perceraian serta tidak dapat rujuk kembali.

f. li'an yaitu talak yang diajtuhkan suami terhadap suami yang mengakibatkan putusnya pernikahan yang selama-lamanya, li'an ini biasanya berdasarkan

JAS: Volume 1 Nomor 2, 2019 
Pandangan Dan Hukum Islam Terhadap Wanita Dalam Masa Iddah

Yang Berhubungan Dengan Pria Lain Melalui Media Sosial.

alasan sang suami menuduh istrinya berbuat zina, atau sang suami berbuat ingkar terhadap anak yang telah dikandung oleh istrinya dan telah lahir dari rahim istrinya, namun sang istri telah menolak tuduhan tersebut. Biasanya li'an ini dilakukan dengan adanya sumpah empat kali terhadap istrinya dengan tuduhan zina dan pengingkaran terhadap anak yang dikandungnya dan diikuti sumpah yang kelima dengan kalimat "laknat Allah atas dirinya apabila tuduhan dan atau pengingkaran tersebut dusta". Disertai dengan penolakan dari sang istri terhadap tuduhan tersebut. (tuduhan berbuat zina dan pengingkaran terhadapa anaka yang dikandungnya) Dengan sumpah empat kali dan diikuti dengan sumpah yang kelima dengan kalimat "murka Allah bila tuduhan dan atau pengingkaran tersebut benar." Li'an ini hanyasah jika dilakukan dihadapan sidang pengadilan agama. Adapun akibat dari perceraian secara li'an ini adalah putusnya perkawinan selamanya, serta untuk penasab an anaknya yakni anak diansabkan terhadap ibu yang mengandungnya. Dan sang suami telah terbebas dari segala kewajibannya. adapun perhitungan talak yakni talak terhitung sejak tanggal perceraian itu dinyatakan di depan sidang pengadilan agama.

Pelaksanaan perceraian selain cerai mati yakni:

1) dalam melakukan talak raj'i dengan cara sindiran (kembalilah kepada orang tuamu, aku bosan dengan kamu) apabila hal tersebut berulang tiga kali maka jatuhlah talak ba'in.

2) Dalam melakukan Talak ba'in sebuah kata yang diucapkan secara langsung (kamu saya cerai).

Adapun akibat dari putusnya perkawinan (talak)

Apabila yang terjadi adalah talak dari perceraian bukan berasal dari kematian maka sang suami wajib memberikan nafkah (mut'ah) yang cukup/layak terhadap istrinya dalam masa iddah baik berupa uang atau benda, kecuali dalam kasus qobla ad-dukhul.adapun ketentuan mut'ah waib diberikan oleh suami terhadap istri dengan syarat belum ditetapkannya mahar oleh suami terhadap istrinya ba'da ad dukhul serta perceraian tersebut atas kehendak suami. Adapun ukuran besarnya mut'ah tergantung dari kepatuhan dan kemampuan sang suami.

Selain itu suami juga wajib memeberikan nafkah, makan, dan kiswah terhadap istrinya selama sang istri dalam masa iddah kecuali dalam kasus talak bai'in nusyuz dan dalam keadaan tidak hamil. Sang suami wajib membayar zakat yang masih belum terbayar (masih terhutang) keseluruhan untuk wanita yang ba'da ad dukhul dan separoh bagi wanita yang ba'da ad-dukhul. Sang suami wajib

JAS: Volume 1 Nomor 2, 2019 
memeberikan hadzanah bagi anak-anaknya masih sampai anak-anak tersebut berusia 21 tahun.

Disisilain sang suami masih dapat kemabli (rujuk) terhadap istrinya yang masih dalam keadaan iddah (masa tunggu). Begitu pula sang wanita/ sang bekas istri wajib menjaga dirinya dalam masa iddah dan tidak memberikan peluang bagi pria lain yang akan meminangnya dan menikahinya ketika dalam keadaan iddah. Selain itu sang wanita/ bekas istri berhak untuk mendapatkan nafkah dari sang laki-laki/ bekas suaminya dalam keadaan iddah kecuali bila sang wanita itu nuyusz.

Menurut Prawirohamidjojo, (1994: 142) Bagi wanita yang telah ditalak suaminya atau telah putus perkawinan dengan sang suaminya maka wajib melakukan iddah (masa tunggu) kecuali dalam keadaan qobla ad-dukhul dan putusnya perkawiman tersebut bukan dikarenakan kematian.

\section{Iddah}

Iddah yaitu waktu tunggu seorang wanita yang telah diceraikan oleh suaminya, di dalam agam Islam iddah didefinisikan dengan sebuah waktu bagi seorang wanita yang telah diceraikan oleh suaminya baik cerai karena suaminya meninggal dunia, ataupun cerai ketika suaminya masih hidup, waktu tunggu untuk menahan diri dari menikah dengan laki-laki lainnya.Dalam pengertian lain, iddah bisa disebut dengan masa perhitungan karena dalam menjalani iddah seorang wanita harus menghitung wkatu suci atau bulan dalam menentukan kapan masa iddah tersebut berakhir. Iddah menurut para ulama:

a. menurut madzhab Hanafi mendefinisikan bahwa iddah adalah sebuah kalimat untuk batasan waktu dan ungkapan untuk menunjukkan apa yang masih tersisa dari bekas nikah.

b. menurut madzhab Maliki mendefinisikan bahwa waktu atau masa yang dijadikan sebagai bukti atas bersihnya rahim karena terjadinya perpisah dalam pernikahan ataupun karena kematian suami atau karena talak dari suami. Seperti yang telah kita ketahui bahwa agama islam telah mewajibkan kepada kita tentang betapa pentingnya kesucian dalam diri manusia. Oleh sebab itu saat terjadi perceraian maka diadakannya iddah yang bertujuan untuk membersihkan rahim.

c. menurut madzhab Syafi'i mendefinisikan iddah sebagai sebuah kata yang menunjukkan kepada sebuah masa. Didalamnya seorang perempuan menunggu untuk mengetahui bersihnya rahimnya atau sebagai bentuk peribadahan kepada Allah, atau untuk menghormati pernikahan dengan suaminya yang terdahulu.

JAS: Volume 1 Nomor 2, 2019 
d. menurut madzhab Hambali mendefinisikan bahwa iddah secara istilah syariat adalah penungguan seorang wanita yang terpisah dengan suaminya disebabkan oleh wafatnya suami atau karena kehidupan suami dengan mentalaknya, atau karena khulu', atau karena perpisahan dengan suami.

Dapat disimpulkan bahwa iddah Menurut para ulama yaitu sebutan masa bagi seoang wanita menunggu/ menanti atau menangguhkan pernikahan setelah sang wanita ditinggal oleh suaminya baik itu ditinggal karena meninggal dunia atau ditinggal karena perceraian, baik itu berakhirnya bulan, atau berakhirnya beberapa quru' ataupun berakhir utnuk kehamilannya (sampai melahirkan)

Wanita yang dalam dalam (menjalani) masa idah disebut mu'tadah. Adapun iddah dibagi menjadi 2 (yakni):

a. iddah bagi wanita yang diceraikan oleh suaminya karena meninggal dunia (mutawaffa 'anha), atau iddah yang dikarenakan pernikahan yang di fasakh dikarenakan pernikahannnya yang haram seperti halanya menikahi dua wanita sekandung atau menikah dengan wanita yang haram untuk dinikahi.

b. iddah bagi wanita yang diceraikan oleh suaminya karena talak ( ghairu mutawaffa 'anha). Dalam hal ini ada dua talak yakni:

1) iddah raj'i yaitu iddah bagi seorang wanita yang ditalak satu atau dua

2) iddah bain yaitu iddah bagi seorang wanita yang ditalak bain oleh suaminya.dalam iddah bain ini sang suami masih diperbolehkan untuk menikahi istrinya lagi dikarenakan talaknya seperti khuluk, pernikahan yang fasakh akibat suami yang menghilang dalam jangka waktu yang lama atau dikarenakan sang suami tidak memberikan nafkah terhadap istrinya, dan lain sebagainya.

Iddah wajib dilaksanakan oleh wanita (istri) untuk memastikan bahwa dirinya sedang hamil apa tidak, hal inilah yang menyebabkan bahwa iddah diwajibkan terhadap wanita. Denngan berbagai ketentuan masanya sesuai dengan jenis perceraiannnya. Apabila ada wanita yang menikah dalam masa iddah dan ternyata wanita tersebut telah hamil, maka anak yang dikandungnya itu akan tidak ada kejelasan tentang ayah yang akan menjadi walinya saat menikah.

Adapun hukum iddah dalam agama Islam adalah wajib bagi seorang wanita yang telah diceraikan oleh suaminya untuk memastikan bahwa dirinya hamil atau tidak. Dasar hukum iddah, Sebenarnya iddah sudah dikanal pada jaman dahulu yakni pada masa jahiliyah (jaman sebelum islam), kemudian setelah kedatangan Islam maka iddah ini masih dipakai (diakui dan diperthankan) oleh sebab itu maka iddah menurut para ulama hukum nya ialah wajib bagi seorang wanita dikarenakan iddah membawa kemaslahatan bagi wanita yang telah ditinggal oleh 
suaminya. Hal ini berdasarkan pada Al quran ayat 228 dan hadist nabi no 4096 Yang berbunyi:

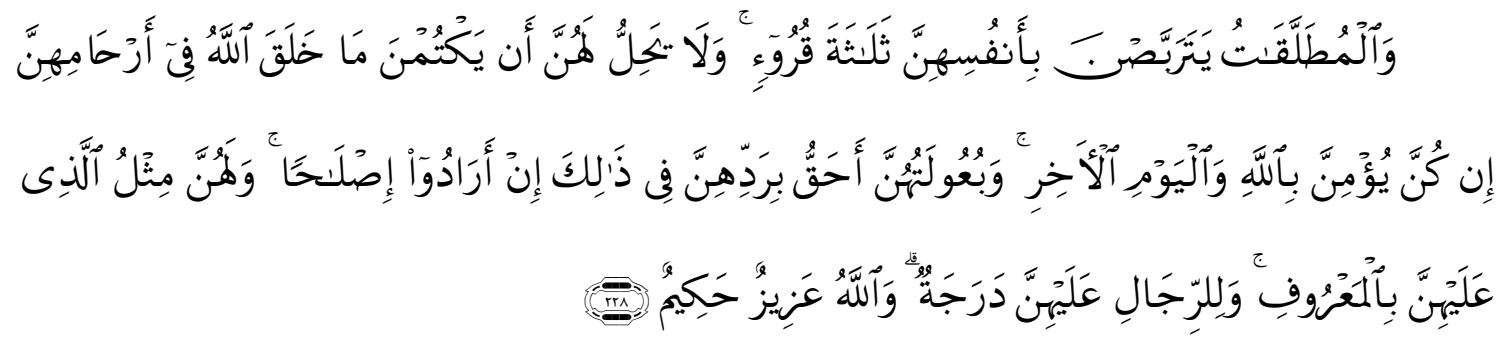

Yang artinya : wanita-wanita yang ditalak handaklah menahan diri (menunggu) tiga kali quru'. tidak boleh mereka Menyembunyikan apa yang diciptakan Allah dalam rahimnya, jika mereka beriman kepada Allah dan hari akhirat. dan suami-suaminya berhak merujukinya dalam masa menanti itu, jika mereka (para suami) menghendaki ishlah. dan Para wanita mempunyai hak yang seimbang dengan kewajibannya menurut cara yang ma'ruf. akan tetapi Para suami, mempunyai satu tingkatan kelebihan daripada isterinya. dan Allah Maha Perkasa lagi Maha Bijaksana.

Sesuai dengan ayat diatas maka jelaslah iddah bagi sorang perempuan diwajibkan, dan seorang permpuan tidak dianjurakn menikah dalam masa iddah sebagai bukti dia benar-benar tidak menyembunyikan apa yang ada didalam rahimnya. Dan selain pada massa iddah suaminya berhak merujukny sebagai bukti bahwa suaminya adalah orang yang bertanggung jawab terhadap keselamatan rumah tangga nya serta dalam kesejahteraannya. Ketentuan Kewajiban dan hak wanita dalam masa iddah yakni:

a. seorang wanita yang dalam keadaan iddah tidak boleh dilihat oleh laki-laki yang bertujuan tertentu (mempersunting wanita tersebut). Namun jika seorang wanita telah dipersuntig oleh seorang laki-laki dalam masa iddah maka wanita tersebut harus menolaknya dengan cara halus (sindiran).

b. Tidak boleh keluar rumah selama masa iddah sekalipun bertujuan ibadah (pergi ke masjid, musholla, takziah, pengajian, dll)

c. Tidak diperkenankan bagii wanita dalam masa iddah untuk berhias/ bersolek sehingga menyebabkan laki-laki tertarik padanya. Dalam berhias ini seperti memakai make-up, perhiasan, wangi-wangian, memakai pakain yang mecolok, dan lain sebagainya.

d. Seorang wanita dalam masa iddah tidak boleh keluar rumah mencari nafkah kecuali dalam keadaan terpaksa (tidak mendapatkan mut'ah dan hadhanah dari mantan suaminya) sebagai kelanjutan kehidupannya seperti: makan, biaya pendidikan anak- anaknya, dan lain sebagainya.

JAS: Volume 1 Nomor 2, 2019 
Pandangan Dan Hukum Islam Terhadap Wanita Dalam Masa Iddah Yang Berhubungan Dengan Pria Lain Melalui Media Sosial.

e. Tidak diperkenankan bagi wanita dalam keadaan iddah untuk melakukan komunikasi dengan laki-laki (yang bertujuan untuk mempersunting meskipun gurauan) meskipun dengan media sosial.

\section{Hak seorang wanita (istri) dalam masa iddah}

Menurut Prawirohamidjojo, (1994:148) Hendaknya para suami mengetahui bahwa seorang istri yang sedang dalam masa iddah masih menjadi tanguungan suami. Dalam sebelum masa iddah berakhir sang istri berhak untuk:

a. Seorang istri yang sedang menjalani masa iddah yang sedang hamil baik itu iddah yang ditalak raj'i ataupun iddah karena talak ba'in maka sang istri berhak untuk mendapatkan pangan, sandang, dan papan dari snag suami sampai iddah tersebut berakhir.

b. Jika perceraiannya dari sang suami dikarennakan sang suami meninggal duani maka sang istri hanya berhak untuk mendapatakan hak waris dari sang suami.

c. Jika wanita yang diceraikan dengan talak bain (talak yang tidak bisa rujuk kembali) atau khulu'(talak yang diajtuhkan suami terhadap istri karena tebusan dari sang istri) maka sang istri dalam masa iddah tidak berhak untuk mendapatkan apapun dari snag suami kecuali tempat tinngal.

Iddah bagi seorang wanita adalah wajib, iddah disebabkan oleh perpisah dari pasangan suami istri yang dikarenakan sang suami meninggal dunia atau sang suami telah menjatuhkan talak terhadapnya (Prawirohamidjojo, 1994: 148). Hikmah iddah yakni:

a. adanya kesempatan rujuk (kembali) menjalani kehidupan rumah tangga apabila keduanya masih bisa/ mungkin untuk bersatu kembali

b. mengetahui terhadap wanita tersebut sednag mengandung atau tidak, dan supaya jelas perwalian terhadap anaknya.

c. Adanya pernghargaan terhadap keduanya utnuk tidak langsung berpindah kecuali iddah tersebut telah berakhir.

d. Adanya kepastian keahilam terhadap wanita tersebut.

e. Syariat Islam telah mensyariatkan masa iddah yang bertujuan menghindari ketidakjelasan terhadap wanita yang telah diapaksa/ditekan untuk segera menikah.garis keturunan (jika keturunannya itu adalah wanita) jika ditpaksa untuk segera menikah.

f. Masa iddah telah menunjuukan betapa agung dan mulia nya akad nikah

g. Masa iddah disyariatkan agar keduanya untuk saling berfikir ulang jika ingin berpisah (putus tali kekeluargaan) terutama pada kasus perceraian

JAS: Volume 1 Nomor 2, 2019 
h. Masa iddah menjaga hak janin berupa nafkan dan lainnya pada wanita yang diceraikan dalam keadaan hamil.

i. Sebagai batas akhir dengan pernikahan sebelumnya

j. Menjaga kebersihan rahim seorang wanita dari pernikahan sebelumnya, sehingga seandainya wanita tersebut telah menikah kemudian hamil maka akan mengahsilkan keturunan yang jelas nasabnya.

k. Hak suami sangat dihargai

l. Jelasnya akhir masa perceraian

m. Sebagai bahan rujukan terhadap wanita yang telah ditalak oleh suaminya kapan masa haidnya.

Dalam hal lain wanita yang dalam masa iddah raj'i haram dan dilarang untuk dipinang, hal ini dikarenakan ada kemungkinan untuk kembalinya sang suami terhadapnya.

para wanita yang telah putus perkawinannya hendaknya menyempurnakan masa iddahnya (masa tunggu) supaya mereka selamat dari kejahatan dan kemaksiatan. Adapun iddah (masa tunggu) bagi wanita yakni:

a. apabila putusnya perkawinan itu disebabkan oleh kematian dan sang wanita/ istri dalam keadaan tidak hamil maka iddahnya 130 hari (4 bulan 10 hari) meskipun wanita tersbut dalam keadaan qobla ad-dukhul

b. apabila putusnya perkawinan itu disebabkan oleh perceraian dan sang wanita masih haidl maka waktu tunggu bagi wanita tersebut adalah 3 kali suci dengan sekurang-kurangnya adalah 90 hari, namun bagi wanita yang keadaan sudah tidak haidh (manopouse) maka ditetapkan masa tunggunya adalah 90 hari.

c. Apabilasang wanita dalam keadaan hamil maka iddah (masa tungg) bagi wanita tersebut adalah sampai melahirkan baik putusnya perkawinan itu disebabkan oleh talak ataupun kematian.

d. Apabila putusnya perkawinan disebabkan oleh talak dan Ketika sang wanita dalam keadaan qobla ad-dukhul maka tidak ada iddah terhadapnya

e. Adapun waktu tunggu bagi wanita yang putus perkawinan disebabkan oleh perceraian, maka waktu tunggu wanita tersebut adalah dimulai dengan tanggal yang tertulis dari dijatuhkannya talak pada pengadilan agama.dan apabila putusnya pernikahan dikarenakan kematian, maka waktu tunggu sang wanita tersebut terhitung sejak tanggal/hari kematiannya suami.

f. Apabila sang wanita pernah haid, dan ketika setelah jatuhya talak ternyata tidak haidl karena menyusui, maka waktu tunggu bagi wanita tersbut adalah tiga kali suci.

g. Apabila sang wanita pernah haidl, dan ketika setelah jatuhnya talak ternyata tidak haidl dan bukan karena menyusui, maka masa tungggu wanita tersbut

JAS: Volume 1 Nomor 2, 2019 
Pandangan Dan Hukum Islam Terhadap Wanita Dalam Masa Iddah Yang Berhubungan Dengan Pria Lain Melalui Media Sosial.

adalah satu tahun dan jika tiba-tiba wanita tersbut haidl, maka iddahnya menjadi tiga kali suci.

h. Apabila seorang wanita yang sedang dalam iddah talak raj'i da tiba-tiba sang suami meninggal dunia maka iddah wanita tersbut menjadi 4 bulan 10 hari. Terhitung sejak tanggal meninggalnya suami.

i. Bagi seorang janda yang putusnya oerkawinan disebabkan oleh khuluk, fasakh, li'an maka berlaku iddh talak baginya.

\section{Perhitungan masa iddah(dari haidh ke hitungan bulan)}

Adapun perhitungan masa iddah bagi wanita tidaklah sama yakni :

a. Masa iddah bagi janda yang ditalak raj'i yakni setara dengan masa iddah janda yang ditinggal mati oleh suaminya yakni 3 kali masa haidl dan 4 kali masa suci atau 4 bulan 10 hari. Dalam hal ini ketika sang suami meninggal duni maka sang janda tetap mendapatkan warisan meskipun sang janda dalam masa iddah.

b. Masa iddah bagi janda yang ditalak ba'in maka sang janda tidak berhak mendapat hak waris atas meniggalnya suami meskipun sang janda tersebut dalam masa iddah serta sang janda tidak berhak menuntut harta waris dari mantan suaminya, karena talak ba'in yang menjadikan putusnya pernikahan selamanya.

\section{Khitbah}

Yang dimaksud dengan khitbah yaitu ajakan atau permintaan dari seorang laki-laki kepada sang wanita baik secara qiyasan (sindiran) atau pun dengan terang-terangan. Namun dalam qiyasan nya mempunyai maksud dan tujuan tertentu. Yakni maksud untuk mengajak menikah kepada sang wanita.

Banyak laki-laki yag mengucapkan khitbah kepada wanita pada saat sang wanita masih dalam keadaan iddah dengan kata sindiran. Sebagai contoh sudah, jangan sedih, banyak laki-laki yang ingin menikah dengan kamu. waktu untuk seorang laki-laki boleh menkhitbah seorang perempuan. menurut para ulama seorang laki-laki boleh berkhitbah kepada seorang wanita jika sang wnaita sudah memenuhi tiga perkara yakni:

1. Wanita tersebut sedang dalam keadaan merdeka (bebas) dari ikatan pernikahan dengan laki-laki lain, atau merdeka (bebas) dari masa iddah, baik itu iddah karena meninggalnya sang suami ataupun iddah karena perceraian.

JAS: Volume 1 Nomor 2, 2019 
2. Wanita tersebut bukanlah wanita yang haram untuk dinikahi. Jika seorang wanita yang haram dinikahi maka wanita tersebut juga haram untuk di khitbah.(ibu, saudara wanita ibu, saudara kandung wanita, dll).

3. Wanita yang merdeka dari khitbah laki-laki lain (wanita yang belum di khitbah oleh laki-laki lain).

Sesuai dengan penjelasan dan kriteria diatas maka para ulama bersepakat bhawa wanita yang masih menjalani masa iddah haram untuk di khitbah, karena masih belum memenuhi salah satu syarat merdekanya (bebasnya) wanita yang boleh untuk di khitbah, baik iddahnya dikarenakan oleh talak raj'i ataupun dikarenakan oleh talak ba'in, ataupun wanita tersebut iddah disebabkan oleh meninggalnya sang suami.

Adapun hikmah dari diharamkan khitbah terhadap wanita yang masih dalam masa iddah yakni: menyelamatkan wanita dari menikah dengan berfikir terlalu cepat, saat sang wanita diajak untuk menikah pada saat iddah maka sang wanita tersebut kemungkinan besar akan menjawab "iya" (akan menerima khitbah dari seorang laki-laki lain) karena emosi yang labil, namun ketika masa iddah berakhir maka kemungkinan besar sang wanita terbeut akan menolak khitbah dari laki-laki lain, karena masih berfikir trauma dengan pernikahannya yang pertama, dan lebih berhati-hati dalam menerima khitbah laki-laki lain, karena emosinya juga sudah mulai stabil.

Dari Ibnu 'Athaniyah berkata bahwa : "para ulama bersepakat bahwa tidak boleh mengucapkan kata-kata yang mengandung ajakan nikah kepada wanita yang masih berada dalam masa iddah"

\section{Hukum mengkhitbah wanita yang masih berada dalam masa iddah}

Adapun hukum mengkhitbah pada saat sang wanita masih dalam keadaan iddah adalah sebagai berikut:

a. Menurut para ulama jika seorang wanita yang dalam masa iddah maka diharamkan untuk menkhitbahnya secara terang-terangan. Jika mengkhitbahnya melaui qiyasan, maka para ulama berbeda pendapat : para ulama hanafiyah membolehkan secara qiyasan, sedangkan yang lain melaranagnya meskipun dengan qiyasan. Dalam hal ini ulama hanafiyah membolehkan mengkhitbah terhadapa wanita dalam masa iddah yang disebabkan oleh kematian bukan wanita dalam masa iddah perceraian, namun jika wanita dalam masa iddah perceraian maka ulama hanafiyah pun berpendapat untuk mengharamkannya.

b. Menurut para ulama jika seorang wanita dalam masa iddah bain maka hukum mengkhitbahnya ada dua yakni boleh namun untuk suami yang

JAS: Volume 1 Nomor 2, 2019 
Pandangan Dan Hukum Islam Terhadap Wanita Dalam Masa Iddah Yang Berhubungan Dengan Pria Lain Melalui Media Sosial.

mengkhitbahnya, dan untuk laki-laki lain yang mengkhitbahnya maka para ulama juga berbeda pendapat ulama malikiyah dan syafi'iyah berpendapat boleh namaun secara qiyasan.

c. Menurut para ualama jika seorang wanita yang dalam masa iddah talak bain kubra, para ulama bersepakat membolehkan mengkhitbah perempuan pada masa iddah. Dalam hal ini yang dijadikan acuan adalah ketika seorang wanita yang ditinggal mati oleh suaminya atau talak bain kubro tidak bisa rujuk (kembali) kepada suaminya.

d. Menurut para ulama jika seorang wanita dalam masa iddah raj'i maka jelaslah wanita tesebut tudak boleh di khitbah, baik secara terang- terangan ataupun qiyasan,

\section{Media sosial chatting}

Pada zaman yang serba instan ini banyak dari masyarakat yang menggunakan media sosial sebagai alat komunikasi, mendia sosial disini yakni alat komunikasi dimana kita bisa berhubungan langsung dengan lawan media.

Pada dasarnya media sosial adalah sebuah media dimana ketika sang penggunanya akan menggunakan nya kita harus terhubung dengan jaringan internet. Dalam hal ini siapapun dapat mengguankannya dengan mudah tanpa ada batasan usia maupun batasan SARA.

Adapun macam-macam media sosial yang sering digunakan dalam masyarakat kita sekarang ini antara lain situs jejaring sosial, dimana dalam jejaring sosial ini para masyarakat dengan mudah untuk bisa berhungan dengan orangorang yang uga menggunakan jearing sosial tersenbut dengan mudah, baik itu sudah kenal sebelumnya maupun yang belum kenal.

Dalam penggunaan jejaring sosial banyak masyarakat yang belum bisa menggunakannya secara tepat, antara lain jejaring sosial sebagai wadah perselingkuhan yang banyak kita lihat selama ini, sebagai alat perantara kebohongan dan lain sebagainya. Namun disisi lain jejaring sosial sangatlah dibutuhkan demi kecepatan komunikasi antara satu dengan yang lainnya. Jejaring sosial yang selama ini ita gunakan seperti WhatsApp, facebook, twiter dan lain-lain adalah sebuah perantara utnuk kita bisa terhubung dengan orang yang juga menggunakannya. Dan terkadang sebagai teman dalam kesepian.

\section{Hukum islam terhadap wanita yang berhubungan dengan pria lain melalui media sosial dalam masa iddah (menkhitbah wanita dalam masa iddah)}

JAS: Volume 1 Nomor 2, 2019 
Padadasarnya islam melarang wanita yang masih dalam iddah berhubungan dengan pria lain baik tiu secara terang-terangan ataupun secara sindiran, hal ini bertujuan agar sang wanita selamat dalam menjalani iddah (masa tunggu). Yang dimaksud dini adalah berhubungan secara langsung maupun berhubungan tidak langsung seperti halnya berhubungan lewat media dengan maksud tertentu.

Hal ini sesuai dengan penjelasan sebelumnya bahwa wanita pada masa iddah dilarang dipinang, yang dimaksud disini alah meskipun itu lewat media sosial atau meminang secara terang-terangan.

Disisi lain sesuai dengan penjelasan diatas bahwa mengkhitbah seorang wanita yang sedag dalamkeadaan iddah tidaklah diperbolehkan meskipun itu secara qiyasan apalagi dizaman sekarang ini yang serba modern haruslah hati-hati terhadap khitbah yang terjadi, bisa bisa khitbah yang terjadi bukan secara ternagterangan atapun qiyansan namun melalui media sosial yang sangat mudah untuk dibuat berhubungan dan kapan saja bisa digunakan.

\section{Larangan wanita iddah di media sosial antara lain :}

a. Berhubungan dengan pria lain dengan maksud dan tujuan

Wanita yang sedang menjalani masa iddah dilarang menggunakan media sosial sebagai sarana untuk menjalin hubungan dengan laki-laki lain selain suaminya (dalam kasus talaq raj'i). Karena yang demikian termasuk qiyas (secara halus). Hal ini sesuai dengan ketentuan dan etika yang harus dijalankan. Karena tidak sesuai dengan ketentun yang disyariatkan dalam agama islam.

b. Berfoto/ berselfi selama masa iddah

Wanita yang sedang menjalani masa iddah hendaknya tidak mengunggah (menguplod) fotonya di medi sosial untuk sementara. Karena jika seorang wanita mengunggah foto dirinya yang sedang masa iddah itu sama halnya ia keluar keluar rumah, meskipun ia tidak tidak sedang keluar rumah, namun wanita tersebut seakan-akan memperlihatkan dirinya di depan umum. Dan Kebanyakan wanita yang mengunggah fotonya bersolek dulu Sehingga Hal yang seperti itu tidak sesuai dengan aturan terhadap tentang wanita masa iddah.

c. Update status yang bisa mengundang laki-laki lain untuk mengkhitbahnya.

Wanita yang sedang menjalani masa iddah hendaknya tidak mengupdates status tentang dirinya yang bisa menimbulkan ketertarikan lawan jenis yang akan mengakibatkan laki-laki lain akan mengkhitbahnya. Karena hal ini tidak sesuai dengan ketentuan bahwa seorang wanita iddah dilarang untuk dikhitbah dan menerima khitbah dari laki-laki yang bukan suaminya.

Kebanyakan orang menggunakan media sosial sebagai sarana untuk dapat berhubungan dengan lawan jenis yang tidak akan diketahui oleh orang-orang JAS: Volume 1 Nomor 2, 2019 
Pandangan Dan Hukum Islam Terhadap Wanita Dalam Masa Iddah Yang Berhubungan Dengan Pria Lain Melalui Media Sosial.

disekitarnya. Namun perbuatan tersebut tetap tidak sesuai dengan Etika dan aturan wanita saat iddah, meskipun sang laki-laki tidak datang kerumanhnya utnuk melihatnya, namun sesuai dengan penjelasan diatas, maka wanita tersebut sama saja dengan menerima khitbah dari seorang laki-laki lain dalam masa iddah, dan hal ini tidak sesuai dengan syariat islam, meskipun itu hanya lewat media sosial (secara tidak langsung). Hendaknya para wanita iddah tetap menjaga kehormatannya ssesuai dengan hukum dan etika yang sudah ditentukan sesui dengan syariat islam baik itu dalam menggunakan media sosial.

Namun keika sang wanita iddah tersebut dalam keadaan talak raj'i dan ia telah menggunakan media sosial untuk berhubungan dengan suaminya maka hal itu dierbolehkan sesuai dengan penjelasan diatas, karena masih memberikan hak suami utnuk kembali.

Hendaknya wanita yang sedang menjalani masa iddah memberikan batasan dalam menggunakan media sosial agar tidak terjadi hal-hal yang diharamkan pada saat menjalani masa iddah. Dan hendaknya para wanita masih menjaga dkehormatan diri dan suaminya pada masa tersebut, karena para wanita iddah masih berstatus istri orang meskipun itu akan terjadi dua kemungkinan (pisah atau kembali) yang pasti.

\section{Simpulan}

Pada hakikatnya Alla SWT membuat ketentuan baik berupa perintah maupun larangan semata-mata untuk kebaikan manusia. Sesuai dengan penjelasan diatas, maka larangan-larang tersebut untuk menghindarkan diri dari kemudhorotan (fitnah) bagi dirinya, dan untuk selalu menjaga kehormatan. hukum Wanita yang berhubungan dengan pria lain dalam masa Iddah melalui media sosial Chatting. Adanya aturan Tidak bolehh meminang wanita yang sedang dalam masa iddah, hal ini dkarenakan:

a. Untuk menjaga kehormatan dirinya dan keluarganya dari fitnah.

b. Untuk menjaga nasab hasil biologis baik dari suami pertama maupun suami yang kedua.

c. Sebagai perwujudtan ketaqwaan terhadap tuhan dengan menjalankan syariaat-Nya.

d. Untuk memperjelas hak dalam mendapatkan bagian waris dari suami.

Penggunaan media sosial seperti chatting, update status, upload foto yang menyatakan dirinya dan mempertontonkan dirinya dalam masa iddah tidak dibenarkan dalam islam karena hal tersebut tidak sesuai dengan ketentuan. Hal tersebut didasarkan pada hukum tentang wnaita iddah tidak boleh keluar rumah,

JAS: Volume 1 Nomor 2, 2019 
Ibnu Jazari

bersolek dan memakai make up, tidak boleh dikhitbah dan menerima khitbah dari laki-laki lain pada masa iddah.

\section{Daftar Rujukan}

Direktorat Pembinaan Agama, Badan Peradilan Agama, Direktorat Jendral Pembinaan Kelembagaan Agama Islam, departemen Agama. 1992. Kompilasi Hukum Islam.

Kuzari, Ahmad. 1995. Nikah Sebagai Perikatan. Jakarta : PT Raja Grafindo Persada.

Prawirohamidjojo, Soetojo. 1994. Pluralisme Dalam Perundang-Undangan Perkawinan di Indonsia. Surabaya : Airlangga University Press.

Taimiyah, Ibnu. 1997. Hukum- Hukum Perkawinan. Jakarta: Puataka Al Kautsar.

Ustman, M. Rafat. 2017. Fikih Khitbah dan Nikah. Depok: Fathan Media Prima

JAS: Volume 1 Nomor 2, 2019 